\title{
Effects of low fat and babassu fat diets on nutritional status in obstructive cholestasis in young rats $^{1}$
}

\author{
Efeitos de dietas com baixo teor de gordura e com gordura de babaçu sobre o estado \\ nutricional na colestase obstrutiva em ratos jovens
}

\author{
Analícia Rocha Santos', Kunie Labuki Rabello Coelho"II Cláudio Antonio Rabello Coelho III

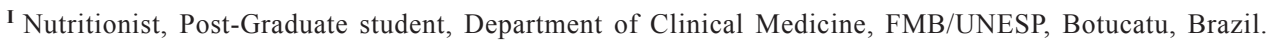 \\ ${ }^{\text {II }} \mathrm{PhD}$, Assistant Professor, Head of the Hepatic Histopathology, Division of the Post-Graduate Course in Pathology, Department of \\ Pathology, FMB/UNESP, Botucatu, Brazil. \\ III PhD, Assistant Professor, Head of the Infant Hepatology Division, Department of Pediatrics, FMB/UNESP, Botucatu, Brazil.
}

\begin{abstract}
Purpose: To test the effects of a low fat diet compared with a babassu fat diet on nutritional status in obstructive cholestasis in young rats. Methods: We submitted 40 rats in 4 groups of 10 animals each from P21 (21 ${ }^{\text {st }}$ postnatal day) to P49 to two of the following treatments: bile duct ligation or sham operation and low fat diet (corn oil supplying $4.5 \%$ of the total amount of energy) or babassu fat diet (this fat supplying $32.7 \%$ and corn oil supplying $1.7 \%$ of the total amount of energy). Weight gain from P25 to P49 every 4 days was measured. The Verhulst's growth function was fitted to these values of weight gain. Growth velocity and acceleration at each moment were estimated using the same equation. Total food and energy intake from P21 to P49, energy utilization rate (EUR) from P25 to P49 and fat absorption rate (FAR) and nitrogen balance (NB) from P42 to P49 were measured. Two Way ANOVA and the S.N.K. test for multiple paired comparisons were employed to study the effects of cholestasis and those of the diets and their interaction $(\mathrm{p}<0.05)$ on those variables. Results: In cholestatic animals, a higher growth velocity at P45, a higher growth acceleration at P41 and P45, a greater EUR, a greater FAR and a greater NB, were found with the low fat diet as compared with the babassu fat diet. Conclusion: A low fat diet lessens the growth restriction brought about by cholestasis and allows for an improved dietary energy utilization and a better protein balance than the babassu fat diet.
\end{abstract}

Key words: Cholestasis. Vegetable Fats. Triglycerides. Rats.

\begin{abstract}
RESUMO
Objetivo: Testar os efeitos de uma dieta com baixo teor de gordura comparada a uma dieta com gordura de babaçu sobre o estado nutricional em ratos jovens com colestase obstrutiva. Métodos: Submetemos 40 ratos divididos em quatro grupos de 10 animais a partir do P21 ( $21^{\circ}$ dia pós-natal) até o P49 a dois dos seguintes tratamentos: ligadura e ressecção do ducto biliar comum ou operação simulada e dieta com baixo teor de gordura (óleo de milho fornecendo $4,5 \%$ da quantidade total de calorias) ou dieta com gordura de babaçu (essa gordura fornecendo 32,7\% e óleo de milho fornecendo 1,7\% da quantidade total de calorias). Foi mensurado o ganho de peso a cada 4 dias do P25 ao P49. A função de crescimento de Verhulst foi ajustada aos valores de ganho de peso. A velocidade e a aceleração de crescimento nos mesmos momentos foram estimadas usando a mesma equação. Foram mensurados: quantidade de ração ingerida e ingestão energética total do P21 ao P49, utilização de energia do P25 ao P49, gordura absorvida e balanço de nitrogênio (BN) do P42 ao P49. A ANOVA com dois fatores e o método de S.N.K para comparações pareadas foram utilizados para estudar os efeitos, sobre as variáveis, da colestase e das dietas e sua interação $(p<0,05)$. Resultados: Em ratos com colestase e dieta com baixo teor de gordura, houve maior velocidade de crescimento no P45, maior aceleração de crescimento no P41 e P45, maior utilização de energia, maior percentual de gordura absorvida e maior BN do que em ratos com colestase e dieta com gordura de babaçu. Conclusão: A dieta com baixo teor de gordura atenua a restrição de crescimento provocada pela colestase e proporciona melhor aproveitamento da dieta e maior incorporação da proteína ingerida do que a dieta com gordura de babaçu.
\end{abstract}

Descritores: Colestase. Gorduras Vegetais. Triglicerídeos. Ratos.

1. Research performed at the Experimental Laboratory, Department of Pediatrics, Botucatu School of Medicine, São Paulo State University (FMB/UNESP), Brazil. 


\section{Introduction}

Cholestasis is defined as every physiopathological alterations in which a decreased or absent biliary flux into the duodenum is present, due to defects in bile secretion or to interference in its transport ${ }^{1,2}$.

Biliary atresia (BA) is the most important cause of cholestasis in infants ${ }^{3}$, since it presents $100 \%$ mortality if left untreated ${ }^{4}$ and is the principal cause for the indication of pediatric liver transplant ${ }^{5}$.

A reduction in the concentration of biliary acids and the consequent malabsorption of fats, are responsible for a considerable reduction in energy utilization of the diet, resulting in malnutrition ${ }^{6}$. In chronic liver disease, malnutrition can contribute to gradual hepatic deterioration and, in many cases, result in death due to liver failure ${ }^{7}$. Malnutrition is the most important factor which interferes in survival, both in patients awaiting transplantation and in those post-transplantation ${ }^{8}$. Prevention or treatment of nutritional deficits allows for improved ponderostatural growth and neuropsychomotor development, as well as lower morbidity ${ }^{7}$.

It has been proposed to substitute medium chain triacylglycerols (MCT) for long chain triacylglycerols (LCT) in the dietotherapy of cholestasis ${ }^{9}$, as the former do not require the action of biliary salts and the formation of micelle in order to be absorbed by the enterocytes and are transported directly into the blood circulation ${ }^{10,11,12}$. Some natural fats contain about $50 \%$ of MCT, such as coconut oil, palm kernel oil and babassu fat ${ }^{13}$. The babassu oil is obtained from the kernel of the fruit of several varieties of the palm Orbignya spp. ${ }^{14}$, native to north region in Brazil.

Deems and Friedman ${ }^{15}$ showed that animals with common bile duct ligature fed on a diet containing coconut oil as a source of MCT, put on significantly more weight than animals fed on a diet composed of LCT.

Deems et al. ${ }^{16}$ showed that cholestatic animals fed on diets rich in fat $30 \%$ of the calories provided by saffron oil) presented higher levels of serum alkaline phosphatase activity, more liver fibrosis and ductal proliferation 28 days after common bile duct ligature, than animals which received a diet poor in fat ( $3 \%$ of total calories). Similarly, Muriel ${ }^{17}$ observed that rats which received Purina chow diet 5001 enriched with 33\% pork fat from P21 to P56 presented more intense liver damage after cholestasis from P56 to P63 compared to animals which were fed a standard Purina chow diet 5001 containing $4.5 \%$ fat.

Our aim was to test, in an experimental model of cholestasis in young rats, the effects of a babassu fat diet in comparison with a low fat content diet using corn oil to provide an adequate amount of essential fatty acids on nutritional status.

\section{Methods}

Experimental design

The independent variables were: 1$)$ the presence or absence of cholestasis (ligature and common bile duct resection or sham operation) and 2) the type of diet (containing triacylglycerols with long chain fatty acids at low concentration or babassu fat).
The dependent variables analyzed were: weight gain from P25 to P49 every four days, growth velocity and acceleration at each moment estimated by the Verhulst's logistic function, total food and energy intake from P21 to P49, weight gain/ energy intake rate from P25 to P49 (energy utilization rate) and fat absorption rate and nitrogen balance from $\mathrm{P} 42$ to $\mathrm{P} 49$.

\section{Experimental procedure}

The experimental procedure was approved by the Ethics in Animal Experimentation Committee of the Botucatu School of Medicine, protocol number 060, 27/09/1999, in according to Ethical Principles in Animal Experimentation accepted by the Brazilian College of Animal Experimentation (Colégio Brasileiro de Experimentação Animal-COBEA $)^{18}$. Animal care, anesthetic, surgical and euthanasia procedures were performed according to the recommendations of the Canadian Council on Animal Care (CCAC) ${ }^{19}$ Guide and of the Guide for the Care and Use of Laboratory Animals (National Research Council-USA) ${ }^{20}$.

\section{Animals and diet}

We studied forty male Wistar rats born in the Pediatrics Experimental Laboratory, of nulliparous females weighing between 180 and 220g, provided by the Animal Center of the Botucatu Campus - UNESP; they were kept in controlled environmental conditions - a temperature of 22 to $23{ }^{\circ} \mathrm{C}$ and light/dark cycle of 12 hours. From birth until P21 (21 $1^{\text {st }}$ postnatal day), they were nursed in groups of six animals. Immediately after weaning they were divided into four groups of ten animals each: 1) group LLF - ligature and common bile duct resection and a low fat content diet (corn oil supplying $4.5 \%$ of the total amount of energy, LF diet); 2) group LBF - ligature and common bile duct resection and a babassu fat diet (this fat supplying $32.7 \%$ and corn oil supplying $1.7 \%$ of the total amount of energy, BF diet); 3) group SLF - sham operation and LF diet; 4) group SBF sham operation and BF diet. From P21 until euthanasia (on P49), they were kept in individual cages, with ad libitum access to water and standardized food according to its group. The dietary compositions can be found in Table 1 . The proportion of fat in each diet was calculated so that the available calories after absorption were similar $-60 \%$ of the $\mathrm{LCT}^{21}$ and $100 \%$ of the $\mathrm{MCT}^{22}$ were considered to be absorbed in the absence of bile acids. The energy value of the MCT is $7 \mathrm{kcal} / \mathrm{g}^{23}$ and of the LCT is $8.84 \mathrm{kcal} / \mathrm{g}^{24}$. 
TABLE 1 - Composition of the diets

\begin{tabular}{|c|c|c|}
\hline & \multicolumn{2}{|c|}{ Diet $^{\mathrm{a}}$} \\
\hline & $\mathrm{LF}$ & $\mathrm{BF}$ \\
\hline \multicolumn{3}{|c|}{ Ingredient, $g / 100 \mathrm{~g}$ diet } \\
\hline Casein & 12 & 12 \\
\hline Sucrose & 10 & 10 \\
\hline Cornstarch & 67 & 43 \\
\hline Babassu fat ${ }^{b}$ & - & 16.3 \\
\hline Corn oil ${ }^{\mathrm{c}}$ & 1.9 & 0.75 \\
\hline Fiber (cellulose) & 4 & 12.9 \\
\hline Mineral mix ${ }^{\mathrm{d}}$ & 4 & 4 \\
\hline Vitamin mix $^{\mathrm{e}}$ & 1 & 1 \\
\hline Sodium benzoate & 0.1 & 0.1 \\
\hline \multicolumn{3}{|c|}{ Diet energy, $\mathrm{kcal} / 100 \mathrm{~g}$} \\
\hline Total energy & 372.8 & 396.1 \\
\hline Available energy ${ }^{f}$ & 366.1 & 363.3 \\
\hline \multicolumn{3}{|c|}{ Essential fatty acids (EFA), $\mathrm{g} / 100 \mathrm{~g}$ diet } \\
\hline Total EFA & 0,65 & 0,85 \\
\hline Available EFA ${ }^{\mathrm{f}}$ & 0,4 & 0,5 \\
\hline \multicolumn{3}{|c|}{ Diet energy distribution, \% total energy } \\
\hline Protein & 12.9 & 12.1 \\
\hline Carbohydrate & 82.6 & 53.5 \\
\hline Total lipids & 4.5 & 34.4 \\
\hline Babassu fat & - & 32.7 \\
\hline \multicolumn{3}{|c|}{ 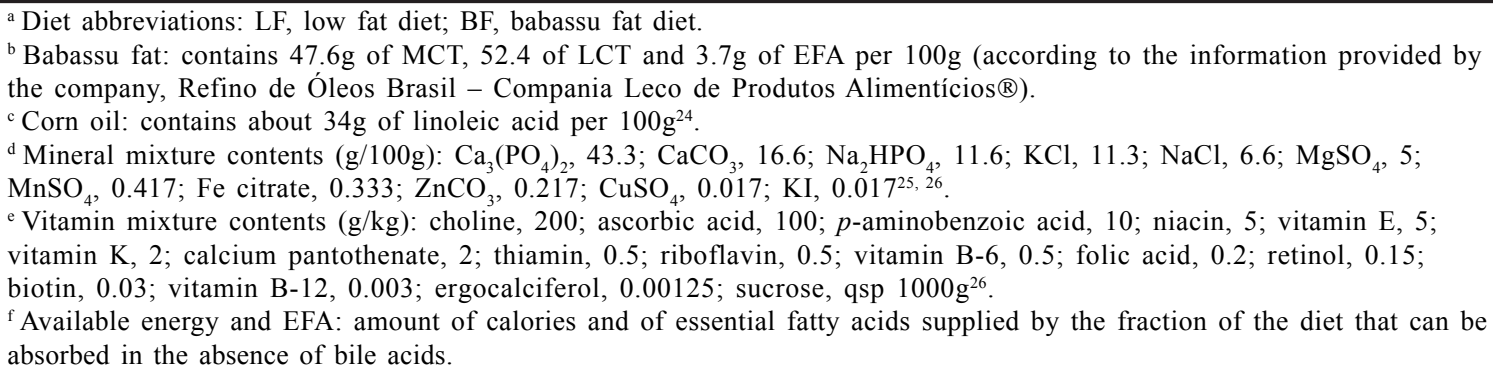 } \\
\hline
\end{tabular}

\section{Surgical technique}

Double ligature and common bile duct resection was performed according to the technique adapted by the UNESP Department of Pediatrics Hepatology Group ${ }^{27}$, from the technique described by Cameron \& Oakley $(1932)^{28}$. The bile duct and the hepatic artery were dissected one from the other, eliminating the possibility of ligating the artery and the duct together. The sham operation followed exactly the same procedure, excepting the double ligature and resection of the common bile duct. During surgery the animals were anesthetized by a $30 \mathrm{mg} / \mathrm{kg}$ dose of pentobarbital i.p. After euthanasia (see below) the hepatic hilum area was inspected in order to rule out any collection of bile or dilatation of the proximal bile duct remnant. The cholestatic liver disease was confirmed by microscopic and microscopic liver examination.

\section{Measurements}

Body weight and the ingestion of each animal were measured daily using a Nagema torsion balance graduated in 0.1 g. From P42 to P49, the animals were kept in individual cages collecting separately urine and feces; the fecal weight and urine volume were recorded daily and the samples were kept refrigerated until the nitrogen determination was carried out by the micro-Kjeldahl method $^{29}$ and the fecal fat content was determined by the gravimetric method with fat extraction by sulfuric ether in a Soxhlet extractor during a 12 hours period. The amount of nitrogen ingested was calculated considering that $1 \mathrm{~g}$ of nitrogen corresponds to $6.25 \mathrm{~g}$ of protein. Nitrogen balance (NB) and the fat aborption rate (FAR) were calculated according to the following formulae:

$$
\begin{aligned}
& \mathrm{NB}=\mathrm{N}_{2} \text { ingested }-\mathrm{N}_{2} \text { eliminated } \\
& \mathrm{FAR}=\quad \text { Fat ingested }- \text { Fat eliminated }{ }_{\text {(feces) }} \mathrm{X} 100 \\
& \text { Fat ingested }
\end{aligned}
$$




\section{Euthanasia}

At P49 the animals were anesthetized with pentobarbital and exsanguinated through a cardiac puncture.

\section{Verhulst's logistic function}

The study of weight gain (WG) was begun at the P25 $\left(25^{\text {th }}\right.$ day postnatal $)$ in order to exclude the period of weight loss due to the surgical procedure. The WG for each animal from P25 until each following moments separated one from the other by four days time was determined. The results of $\mathrm{WG}$ for each moment and for each experimental group were fitted to the Verhulst's function using the Marquardt-Loewenberg algorithm, using the Sigma Stat 2.0 program. With the estimated WG values and the estimated parameters a and $\mathrm{g}$, the values of growth velocity (first derivative of the logistic function) and growth acceleration (second derivative of the logistic function) were calculated ${ }^{30}$.

\section{Statistical methods}

The means and standard deviations of each measured variable for each experimental group were calculated. The effects of: 1) the surgical procedure independently of the type of diet, 2) the type of diet independently of the surgical procedure and 3) the interaction of both factors were studied using a two way ANOVA (Sigma Stat program for Windows Version 2.0, Copyright(C) 1992-1995, Jandel Corporation) according to the following steps:

1) testing for normality and equality of variances of the values obtained for each group;

2) a two way analysis of variance was applied: considering as factor 1 the type of diet; and as factor 2 the presence or absence of cholestasis;

3) when a significant interaction between the factors occurred $(\mathrm{p}<0.05)$ multiple paired comparisons using the Student-Newman-Keuls method (S.N.K.) was realized, identifying pairs of groups with significant differences between them;

4) if a sample did not pass the tests of item 1, mathematical transformations of the data were made and the transformations which passed the tests were analyzed. This was the case for the fat absorption rate and the growth acceleration at $\mathrm{P} 41$, which were substituted by its rank number.

\section{Results}

Cholestasis began to exert its effect on weight gain (WG) from P41 (Figure 1). Dietary effects on WG were only demonstrated when considering WG up to P49 - the administration of the BF diet increased WG in the animals without cholestasis $(\mathrm{SBF}>\mathrm{SLF})$ and was associated with reduced $\mathrm{WG}$ in animals with cholestasis $(\mathrm{LBF}<\mathrm{SBF})$; the $\mathrm{LF}$ diet avoided the effect of cholestasis on WG (LLF»SLF), but no significant difference occurred between the two groups with cholestasis (LLF and LBF) (Figure 1).

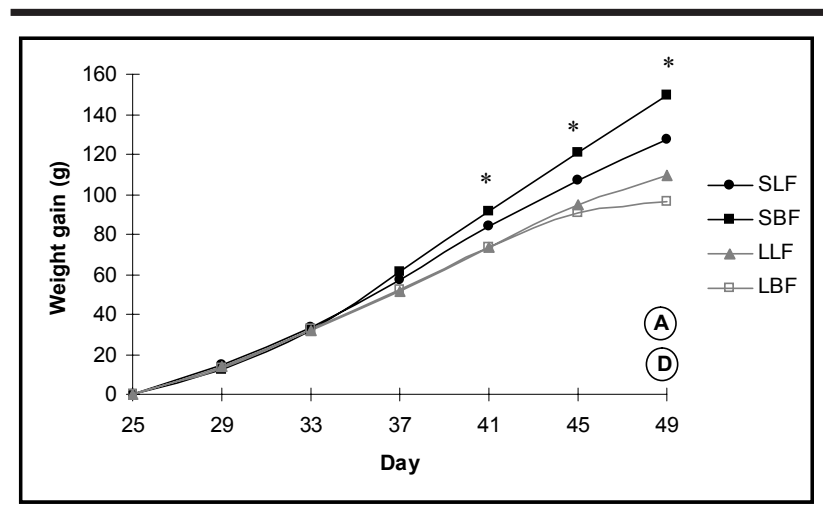

FIGURE 1 - Mean weight gain observed (g) in the four groups, from P25 to P49 with four day intervals. LBF: group with ligature and common bile duct resection and babassu fat diet; LLF: group with ligature and common bile duct resection and low fat diet; SBF: group with sham operation and babassu fat diet; SLF: group with sham operation and low fat diet. A statistically significance was accepted when the probability of error $\alpha$ was less than 0.05 . ${ }^{*}$ Effect of cholestasis (SLF + SBF vs. LLF + LBF significantly different); the letters A and D represent a significant difference between groups $(\mathrm{A}=\mathrm{SLF} v s . \mathrm{SBF} ; \mathrm{D}=\mathrm{LBF} v s . \mathrm{SBF})$

As indicated in Figure 2, cholestasis began to exert its effect on the growth velocity $(\mathrm{GV})$ from $\mathrm{P} 37$. At P41 and $\mathrm{P} 47$, the effects of diet were demonstrated on $\mathrm{GV}$ - the administration of the BF diet increased GV in animals without cholestasis $(\mathrm{SBF}>\mathrm{SLF})$ and was associated with reduced $\mathrm{GV}$ in animals with cholestasis $(\mathrm{LBF}<\mathrm{SBF})$; the $\mathrm{LF}$ diet avoided the effect of cholestasis on GV (LLF»SLF) and at $\mathrm{P} 45$ was associated to a $\mathrm{GV}$ greater than that associated with BF diet in animals with cholestasis (LLF $>$ LBF) (Figure 2).

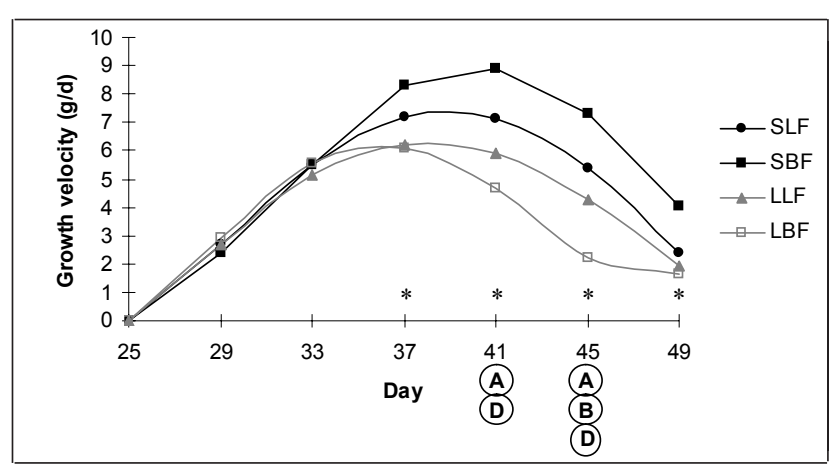

FIGURE 2 - Mean growth velocity observed (g) in the four groups, from P25 to P49 with four day intervals. LBF: group with ligature and common bile duct resection and babassu fat diet; LLF: group with ligature and common bile duct resection and low fat diet; SBF: group with sham operation and babassu fat diet; SLF: group with sham operation and low fat diet. A statistically significance was accepted when the probability of error $\alpha$ was less than 0.05 . *Effect of cholestasis (SLF + SBF vs. LLF + LBF significantly different); the letters $\mathrm{A}, \mathrm{B}$ and $\mathrm{D}$ represent a significant difference between groups (A=SLF vs. SBF; B=LLF vs. LBF; $\mathrm{D}=\mathrm{LBF} v s . \mathrm{SBF})$ 
The growth acceleration (GA) at P25 was greater in animals with cholestasis than in animals without cholestasis, independently of diet, but at P29 it was similar in all groups (Figure 3). Cholestasis began to exert its effect on GA from P33 onwards. Dietary effects on GA were demonstrated at P41 and P45 - the LF diet was associated with a greater GA than the $\mathrm{BF}$ diet in animals with cholestasis ( $\mathrm{LLF}>\mathrm{LBF}$ ); the $\mathrm{BF}$ diet did not avoid the effect of cholestasis on GA $(\mathrm{LBF}<\mathrm{SBF})$ (Figure 3).

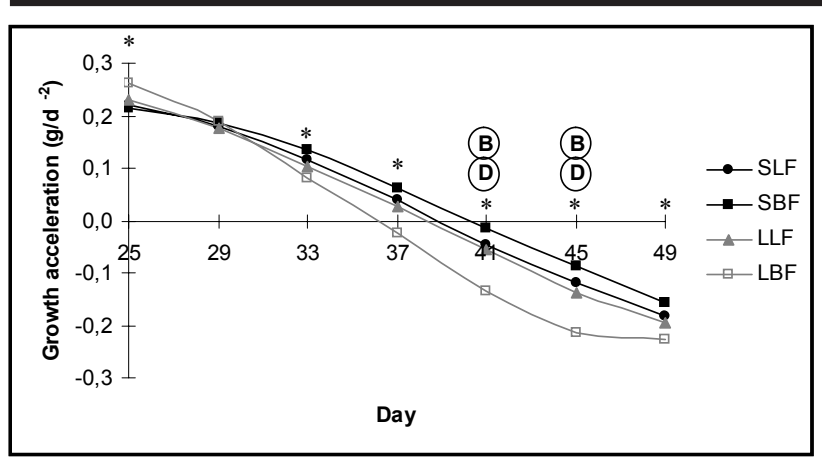

FIGURE 3 - Mean growth acceleration observed (g) in the four groups, from P25 to P49 with four day intervals. LBF: group with ligature and common bile duct resection and babassu fat diet; LLF: group with ligature and common bile duct resection and low fat diet; SBF: group with sham operation and babassu fat diet; SLF: group with sham operation and low fat diet. A statistically significance was accepted when the probability of error $\alpha$ was less than 0.05 . *Effect of cholestasis (SLF + SBF vs. LLF + LBF significantly different); the letters B and D represent a significant difference between groups (B=LLF $v s$. LBF; $\mathrm{D}=\mathrm{LBF} v s$. SBF)
Cholestasis, independently of the type of diet, was associated with a decrease in food and energy intake $[(\mathrm{LLF}+\mathrm{LBF})<(\mathrm{SLF}+\mathrm{SBF})]$. The type of diet, independently of cholestasis, had no effect on the food and energy intake (Table 2).

The type of diet had no effect on energy utilization in rats without cholestasis $(\mathrm{SLF} \approx \mathrm{SBF})$. LF diet significantly increased energy utilization over BF diet in animals with cholestasis (LLF $>$ LBF). The BF diet did not avoid the effect of cholestasis on energy utilization $(\mathrm{LBF}<\mathrm{SBF})$ (Table 2).

Cholestasis decreased the fat utilization rate (FAR) both in animals with $\mathrm{BF}$ diets $(\mathrm{LBF}<\mathrm{SBF})$ and in animals with $\mathrm{LF}$ diets ( $\mathrm{LLF}<\mathrm{SLF}$ ), but the LF diet led to greater FAR than the BF diet in animals with cholestasis (LLF $>$ LBF). The type of diet had no influence in the FAR in rats without cholestasis (SLF $\approx \mathrm{SBF})$ (Table 2).

The type of diet had no influence in the nitrogen balance $(\mathrm{NB})$ in rats without cholestasis $(\mathrm{SLF} \approx \mathrm{SBF})$; cholestasis decreased the NB both in animals with BF diets $(\mathrm{LBF}<\mathrm{SBF})$ and in animals with $\mathrm{LF}$ diets $(\mathrm{LLF}<\mathrm{SLF})$, but in the latter the reduction was less marked. The LF diet was associated with a higher nitrogen utilization than the $\mathrm{BF}$ diet in animals with cholestasis (LLF $>$ LBF) (Table 2).

TABLE 2 - Food and energy intake, total body weight gain and nutrient utilization (energy, fat and nitrogen) of the four experimental groups ${ }^{\mathrm{a}}$

\begin{tabular}{|c|c|c|c|c|}
\hline \multirow[b]{3}{*}{$\begin{array}{l}\text { Food intake from } \mathrm{P} 21 \text { to } \mathrm{P} 49, g * \\
\text { Energy intake from } \mathrm{P} 21 \text { to } \mathrm{P} 49, \mathrm{kcal} * \\
\text { Total weight gain from } \mathrm{P} 25 \text { to } \mathrm{P} 49, \mathrm{~g} * \\
\text { Energy utilization rate } \mathrm{c}, \mathrm{g} / \mathrm{kcal} * \\
\text { Fat absorption rate, } g / 100 \mathrm{~g} * \dagger \\
\text { Nitrogen balance, } g^{*} \dagger\end{array}$} & \multicolumn{4}{|c|}{ Experimental groups ${ }^{b}$} \\
\hline & SLF & SBF & LLF & LBF \\
\hline & $\begin{array}{l}334.47 \pm 47.00 \\
1246.89 \pm 175.21 \\
127,49 \pm 18,00^{\mathrm{A}} \\
0.1090 \pm 0.00735 \\
98.70 \pm 0.87^{\mathrm{C}} \\
1.817 \pm 0.271^{\mathrm{C}}\end{array}$ & $\begin{array}{l}354.07 \pm 61.58 \\
1402.46 \pm 243.90 \\
149,75 \pm 24,92^{\mathrm{AD}} \\
0.1150 \pm 0.00655^{\mathrm{D}} \\
97.97 \pm 2.22^{\mathrm{D}} \\
1.831 \pm 0.221^{\mathrm{D}}\end{array}$ & $\begin{array}{l}280.49 \pm 49.89 \\
1045.66 \pm 185.97 \\
109,66 \pm 24,82 \\
0.1090 \pm 0.00704 \\
91.17 \pm 1.65^{\mathrm{BC}} \\
1.275 \pm 0.466^{\mathrm{BC}}\end{array}$ & $\begin{array}{l}264.31 \pm 53.64 \\
1046.91 \pm 212.46 \\
96,50 \pm 22,48^{\mathrm{D}} \\
0.0967 \pm 0.00651^{\mathrm{BD}} \\
73.93 \pm 9.27^{\mathrm{BD}} \\
0.598 \pm 0.420^{\mathrm{BD}}\end{array}$ \\
\hline
\end{tabular}




\section{Discussion}

The results indicate that the $\mathrm{BF}$ diet increased the weight gain of rats without cholestasis probably due to the greater fat content of this diet, since there was no significant difference regarding the caloric ingestion between these animals (SBF and SLF). The BF diet reduced WG in rats with cholestasis as compared with the LF diet. This is in agreement with the lower utilization of the dietary fat and lower caloric ingestion in rats with cholestasis. This finding is explained by the malabsorption of fat which occurs with cholestasis, as lipids constitute a larger portion of the $\mathrm{BF}$ diet than the LF diet. The fat utilization in the diet with babassu fat, with cholestasis, is insufficient to equal the utilization of other nutrients in the diet with little fat. The MCT content of babassu fat in the BF diet, although it is better absorbed than long chain triglycerides, was not able to compensate for its LCT content ${ }^{12,31}$.

Based on the variables related to nutrition and growth, we suggest that the LF diet attenuates the growth retardation due to cholestasis and that the $\mathrm{BF}$ diet promotes weight increase in the absence of cholestasis, but does not avoid the effect of cholestasis on growth retardation.

One should notice that GA, GV and WG began to show effects of cholestasis at P33, P37 and P41 that is, effect on AC preceded the effect on GV and this preceded that on WG. Accordingly, the effect of BF diet on GA of cholestatic animals preceded its effect on GV (Figures 1, 2 and 3).

Deems et al. ${ }^{16}$ found that adult rats with common bile duct ligature using diets with safflower oil supplying $3 \%$ of the total energy put on more weight than rats fed diets with safflower oil supplying $10 \%$ and $30 \%$ of the total energy. This is in agreement with our finding that cholestatic rats fed a low fat diet had higher growth acceleration at P41 and P45 and higher growth velocity at p45 than cholestatic rats fed a diet with babassu fat supplying $32.7 \%$ of the total energy content.

Cholestasis resulted in a lower NB, both in animals receiving the $\mathrm{BF}$ diet and in those receiving the $\mathrm{LF}$ diet, suggesting that the utilization of nutrients is less efficient or that increased catabolism occurs, which is in agreement with results found in the literature ${ }^{32}$. Alterations in the metabolism of aminoacids and an increase in energy expenditure, together with a reduction in protein synthesis and accelerated protein catabolism ${ }^{33}$ can contribute to a negative NB in cholestasis. According to Pierro et al. ${ }^{33}$, it is probable that carbohydrates were predominantly metabolized in cholestasis, as was shown by measurements of respiratory coefficient, and that protein is used preferentially as an energy source due to hypercatabolism.
In that study, protein oxidation was approximately $17 \%$ and the nitrogen balance close to zero. In the absence of cholestasis, the contribution of protein oxidation in energy consumption is around 4 to $9 \%{ }^{34}$. Our results are in agreement with these studies since rats receiving the LF diet presented a less accentuated effect of cholestasis on NB and on energy utilization.

\section{Conclusion}

The diet with a lower fat content, containing LCT in sufficient quantity to meet essential fatty acid needs, and higher carbohydrate content allows for a better utilization of ingested protein and better utilization of diet energy for growth in cholestasis than a high fat and high medium chain triacylglycerols diet. Therefore studies in humans are warranted to test the validity of such effects.

\section{References}

1. Popper H. Cholestasis. Annu Rev Med. 1968;19:39-56.

2. Poupon R, Chazouillères O, Poupon RE. Chronic cholestatic diseases. J Hepatol. 2000;32(Suppl. 1):12940.

3. Burdelski M. Current concepts in diagnosis and therapy of pediatric liver diseases. J Hepatol. 1995;23(Suppl. 1):45-8.

4. Balistreri WF, Grand R, Hoofnagle JH, Suchy FJ, Ryckman FC, Perlmutter DH, Sokol RJ. Biliary atresia: current concepts and research direction. Hepatology. 1996;23:1682-92.

5. Otte JB. History of pediatric liver transplantation. Where are we coming from? Where do we stand? Pediatr Transplant. 2002;6:378-87.

6. Teran JC. Nutrition and liver diseases. Curr Gastroenterol Rep. 1999;1:335-40.

7. Shepherd RW. Nutritional support of the child with chronic liver disease. In: Suchy FJ. Liver disease in children. St. Louis: Mosby; 1994. p.389-400.

8. Shepherd RW, Chin SE, Cleghorn GJ, Patrick M, Ong TH, Lynch SV, Balderson G, Strong R. Malnutrition in children with chronic liver disease accepted for liver transplantation: clinical profile and effect on outcome. J Paediatr Child Health. 1991;27:295-9.

9. Cohen MI, Gartner LM. The use medium-chain triglycerides in the management of biliary atresia. J Pediatr. 1971;79:379-84.

10. Senior JR. The place of medium chain triglycerides. Am J Med Sci. 1969;257:75-80.

11. Ockner RK, Pittman JP, Yager JL. Differences in the intestinal absorption of saturated and insaturated long chain fatty acids. Gastroenterology. 1972;62:981-92.

12. Bach AC, Babayan VK. Medium-chain triglycerides: an 
update. Am J Clin Nutr. 1982; 36:950-62.

13. Babayan VK. Medium-chain triglycerides - Their composition, preparation, and application. J Am Oil Chem Soc. 1968;45:23-5.

14. Codex Alimentarius Commission. Codex Standard for Named Vegetable Oils. Codex Stan 210-1999. Rome: Food and Agriculture Organization of the United Nations/ World Health Organization; 2001. v.8. p.11-25.

15. Deems RO, Friedman MI. Macronutrient selection in an animal model of cholestatic liver disease. Appetite. 1988;11:73-80.

16. Deems RO, Skypala PL, Hernandez AM, Friedman LS, Friedman MI. Dietary fat exacerbates liver disease in bile duct-ligated rats. J Nutr. 1993;123:1414-20.

17. Muriel P. High fat diet and liver damage induced by biliary obstruction in the rat. J Appl Toxicol. 1995;15:1258.

18. Comissão de Ensino do Colégio Brasileiro de Experimentação Animal (COBEA) - Manual para técnica em bioterismo; 1996.

19. Canadian Council on Animal Care. Guide to the care and use of experimental animals. v.2. Ottawa, Ontario: CCAC; 1984.

20. National Research Council. Guide for the care and use of laboratory animals. Washington DC: National Academy Press; 1996.

21. Vlahcevic ZR, Heuman DM, Hylemon PB. Physiology and pathophysiology of enterohepatic circulation of bile acids. In: Zakim DE, Boyer TD. Hepatology: a textbook of liver disease. 2ed. Philadelphia: Saunders; 1992. p.376-417.

22. Protheroe SM. Feeding the child with chronic liver disease. Nutrition. 1998;14:796-800.

23. Alpers DH, Clouse RE, Stenson WF. Manual of nutrition therapeutics. Boston: Little Brown; 1983.

24. United States Department of Agriculture (USDA). Composition of foods: fats and oils - raw, processed, prepared. Agriculture Handbook 8-4. Washington, DC: US Government Printing Office; 1979.

25. Fox MRS, Briggs GM. Salt mixtures for purified type diets. III. An improved salt mixtures for chicks. J Nutr. 1960;72:242-50.

26. Lajolo FM, Campos França MH, Zucas SM. Importância da cor da ração no consumo da mesma por ratos (Ratus norvegicus var albinus). Rev Fac Farm Bioquim. 1969;7:95-103.

27. Battochio APR, Santos AG, Silva CRM, Santos AR, Coelho CAR. Adaptação do modelo experimental de colestase extra-hepática em ratos jovens. Acta Cir Bras. 2004; 19:70-3.

28. Cameron GR, Oakley CL. Ligation of the common bile duct. J Pathol Bacteriol. 1932;35:769-99.

29. Kjeldahl. Association of official and agricultural chemists: official methods of analysis. 8ed. Washington DC; 1965.

30. Hoffmann R, Vieira S. Análise de regressão: uma introdução à econometria. São Paulo: HUCITEC EDUSP; 1977.

31. Linscheer WG, Patterson JF, Moore EW, Clermont RJ, Robins SJ, Chalmers TC. Medium and long chain fat absorption in patients with cirrhosis. J Clin Invest. 1966;45:1317-25.

32. Descos BP, Berry SA, Sharp HL, Gross CR, Weisdorf $\mathrm{SA}$, Pescovitz OH. Growth failure in cholestasis rats: the effect of malnutrition on insulin-like growth factor 1. Pediatr Res. 1989;26:410-4.

33. Pierro A, Koletzko B, Carnielli V, Superina RA, Roberts EA, Filler RM, Smith J, Heim T. Resting energy expenditure is increased in infants and children with extrahepatic biliary atresia. J Pediatr Surg. 1989a; 24:5348.

34. Pierro A, Carnielli V, Filler RM, Smith J, Heim T. Metabolism of intravenous fat emulsion in the surgical newborn. J Pediatr Surg. 1989b; 24:95-102.

\section{Correspondence:}

Analícia Rocha Santos

R. São Marcelo, 70

45600-000 Itabuna - BA

Phone: (55 73)3211-9639

analiciarocha@ig.com.br
Conflict of interest: none Financial source: CAPES

Received: August 21, 2007

Review: October 25, 2007

Accepted: November 20, 2007

\section{How to cite this article}

Santos AR, Coelho KLR, Coelho CAR. Effects of low fat and babassu fat diets on nutritional status in obstructive cholestasis in young rats. Acta Cir Bras. [serial on the Internet] 2008 Jan-Feb;23(1). Available from URL:

$\underline{\text { http://www.scielo.br/acb }}$ 